\title{
Puberphonia: from classic to modern approach
}

\section{Bojana Vuković, Sladjana Ćalasan}

\author{
University of East Sarajevo, \\ Faculty of Medicine Foca, \\ The Republic of Srpska, \\ Bosnia and Herzegovina
}

Primljen - Received: 21/01/2021

Prihvaćen - Accepted: 26/03/2021

\section{Corresponding author:}

Bojana Vuković, MA

Nemanjina 1, 73300 Foca

bvukovic75@yahoo.com

Copyright: @2021 Bojana Vuković \& Sladjana Ćalasan. This is an Open Access article distributed under the terms of the Creative Commons Attribution 4.0 International (CC BY 4.0) license.

\begin{abstract}
Summary
Voice is a significant component of communication that allows us to express information and emotions, so it is the foundation of verbal communication. Maturation of the body involves dilation of the lar$\mathrm{ynx}$ and lower positioning of the larynx in the neck, resulting multiple changes in voice quality. The rapid changes in the human larynx during puberty are more evident in males. Such changes can result in voice mutation - puberphonia. Puberphonia, also called mutational dysphonia or mutational falsetto, is the failure of a natural decrease in fundamental frequency or pitch. We can also defined puberphonia as persistent adolescent voice even after puberty in the absence of organic cause. This functional voice disorder can have multiple consequences on the personality and quality of life of an individual that often encounters problems that include psychological, emotional, social, and professional difficulties. This article aims to review the relevant and accessible literature on puberphonia in a comprehensive concise manner, highlighting the etiology, prevalence, clinical manifestation, consequences on quality of life, as well as evolution of the approach and attitude to its treatment.
\end{abstract}

Key words: voice mutation, puberty, puberphonia

\section{Introduction}

During ontogenetic development, a human goes through two very distinct biological phases of his development, which visibly affect his physical and mental state. In the first phase is the biological ascent, puberty, or the age of significant changes in the child's body and a major turning point in boys and girls, and the second is the biological decline, or menopause. Both phases significantly affect an individual's voice. Numerous literature in the field of speech therapy, acoustics, phonetics, phoniatrics, psychology, psychiatry, vocal pedagogy, as well as individuals' own experiences testify to the importance of voice and speech in human communication [1]. Voice is a multidimensional whole that allows us to express information and emotions, so it is the foundation of verbal communication [2]. It is a product of the synergy of several systems: respiratory, phonatory, resonant and articulatory systems. We are often not sufficiently aware of the importance of the voice and the information it gives us. By listening 
to someone's voice, we can get information about the speaker's physical characteristics and also more subtle information, such as temperament, intention, emotion, or mood [3]. As we mentioned earlier, the period of puberty is a period of intense changes in an individual's voice. Puberty occurs and lasts very individually. In some it occurs earlier, in some later, and that depends on several factors, such as environment, diet and genetics. In our area, the maturation of girls occurs between the ages of 12 and 15, and in boys between the ages of 13 and 16. The duration of puberty, and therefore the mutation of voice, cannot be precisely determined. Voice mutation or so-called puberphonia is a change in the vocal apparatus due to the growth of the larynx and its muscles, and the enlargement of the vocal cords. It is a transitional period of changing the voice of a child into the voice of an adult. If not properly treated or given importance, this functional voice disorder can have multiple consequences on the personality and quality of life of an individual, so we believe that it is important to review relevant and available literature, make a review of knowledge about this voice disorder, which will be useful to both, clinicians and scientists.

\section{Definition, etiology and prevalence of puberphonia}

Mutation of the voice during puberphonia is a functional disorder which is manifested as the voice with the children's characteristics after puberty. The appearance of voice in a higher level or in the voice register is the main symptom that lasts even after puberty. The voice of patients is continuous and weak for a long time, thin, breathable, hoarse, feminized and immature. Other symptoms are pitch interruptions, inadequate resonance, and shallow breathing $[4,5]$. Other terms used to describe this condition include puberphonia, adolescent transitional dysphonia, persistent falsetto, incomplete mutation, and mutational falsetto [6].

The etiology of this voice disorder has not been fully elucidated. However, it is considered that the main cause is the influence of testosterone and growth hormone with incompatible growth of the larynx, especially the vocal cords. A recent study shows that there are aberrant hormonal changes in people with puberphonia, expressed through higher values of GPER-1, 17 $\beta$-HSD, as well as cAMP compared to the control group [7]. During puberty, developmental mutations are observed in both males and females. However, this change is more obvious in boys compared to girls. During this period, the larynx descends, and its dimensions in the sagittal and transverse planes increase. In men, the angle of the thyroid cartilage decreases to $90^{\circ}$, the length of the vocal cords increases, and the dimension of the epiglottis decreases. Changes that occur during puberty in all organs responsible for phonation include an increase in respiratory capacity, because the length and extent of the breast also increase [8]. The neck increases in length and width, which leads to a relative lowering of the larynx and a consequent expansion of the vocal tract, which increases the resonatory system. The growth of the paranasal sinuses also changes the quality of the voice. The vibrational source, the vocal cords, is therefore only one of several parts of the vocal apparatus that change size during puberty, but the fundamental frequency of the voice is directly related to the vibration of the vocal cords [9]. In addition to these causes, the etiological factors include emotional stress, delayed development of secondary sexual characteristics, psychogenic causes and excessive maternal protection [10].

Voice frequency in men falls by approximately one octave. The voice remains in high intonation, but occasionally it breaks and there is a mixing of the chest register and the head register. The vocal register is a psychoacoustic 
term and the term "register" was used to perceptually describe different registers of voice quality contained in certain tone ranges. The three main modes of phonation are classified as laryngeal modes or registers. These are chest, middle and head registers. These three registers usually correspond to frequency ranges: low, medium, and high [11]. The typical fundamental frequency of an adult male is between $85-180 \mathrm{~Hz}$, and of an adult female around $165-255 \mathrm{~Hz}$ [12]. The characteristic of puberphonia is that a boy continues to use higher tonality that strains the laryngeal muscles. Therefore, the voices of girls and boys that show similarities before puberty, after this period differ significantly in gender and voice quality in terms of specific, low frequencies in men $[8,13]$. There are three phases in the mutation period (9-16 years). In the permutation phase, the first symptoms of mutational voice change appear at the age of 9 to 10 years. The main mutational phase is characterized by a rough, hoarse voice quality and a successive decrease in pitch over a relatively short period of time; it can take several months. The postmutation phase is the last phase and involves the stabilization of the male voice; it is characterized by lowering the volume range and stabilizing the pitch. Most adolescents complete the mutation phase at the age of 17 .

Although mutational falsetto is a temporary voice, in cases when it is not treated, it can turn into a chronic voice disorder [14]. Especially, if resonance is interrupted during vocal performance and if voice control is reduced, it can negatively affect men in early adolescence in a psychosocial sense [15]. Vocal therapy in this case, as with all other voice problems, helps the individual to regain a healthy voice in accordance with their age and gender. Applied vocal therapy increases the voice quality of young people and adults, helping them to control vocal performances. The prevalence of this voice disorder has not been clearly established, there is a lack of epidemiological studies that deal with this issue.
However, research done in India finds that the prevalence is 1 per 900,000 inhabitants [16]. Also, some studies find that of all voice disorders $2-3 \%$ are mutational falsetto, or puberphonia [17]. Other studies that address this problem always refer to this frequency data, as no more comprehensive study has been done to examine the prevalence of this voice disorder.

\section{Puberphonia and quality of life}

The human voice is an individual product of the interaction of a complex physiological function that reveals uniqueness, because individuals can be recognized by voice $[18,19]$. The personal characteristics of the voice heard by the person-listener can shape the flow of communication [20]. When vocal characteristics deviate from gender, age and culturology in the background of the expected norm, the sound of the voice can attract more attention than the messages themselves. Therefore, it is not surprising that individuals with a voice disorder can be identified by their voice disorder instead of the whole personality [21,22]. In the same way, the detrimental consequences of voice impairment include the risk of losing social role [23]. Typical psychologically accompanying problems of chronic illness in general, as well as in persistent voice disorders, include depression, anxiety, and tension [24]. Voice production is a critical component of social interactions. It is therefore clear that as a consequence of voice disorders, detrimental effects on the quality of life of people are imposed [23]. The impact of voice disorders varies from person to person. Occupation, environment, family members, and complete personality are all variables that can affect the way a voice disorder affects a particular person [25]. People with puberphonia often encounter problems that include psychological, emotional, social, and professional difficulties [26]. In recent 
decades, more and more attention has been focused on health-related quality of life, and research conducted by Wilson et al stressed the importance of including quality of life measures in voice assessment [27]. That is how the instrument, the so-called The Voice Handicap Index (VHI) was developed and validated by Jacobson et al. [28]. It was initially developed to meet the patient's requirements in terms of treatment outcomes with an emphasis on the patient's physical, emotional and functional changes during treatment. The first version of this instrument had 85 items, and then it was reduced to 30 items as VHI-30, which is also the most popular scale used in clinical practice, as well as in research [29]. Each VHI subscale tends to score 40 , giving a total of 120 . A VHI score of 0 to 30 represents low score indicating that there is a minimal handicap associated with voice disorder. A score of 31 to 60 indicates a moderate handicap as a result of a voice disorder. Then, a VHI score of 60 to 120 represents a significant and severe handicap due to voice problems and is often seen in patients with vocal cord paralysis or vocal cord scar. Many researchers reported that $\mathrm{VHI}$ is a useful tool for monitoring treatments for a wide range of voice disorders [30,31]. VHI is also used to assess the effect of voice disorders on a patient's daily life [28]. Also, the overall VHI score is taken as the change between the VHI score before and after the intervention, and the scores on the VHI subscales may be important for assessing treatment options and outcomes. In addition to the impact on voice, this disorder also has an impact on the social and psychological levels.

The effects of puberphonia in men include: physical/mental health; destroys their self-respect; leads to low self-esteem, self-doubt, anxiety and depression; worrying behavior; obsessive thoughts about yourself; eating disorders such as anorexia and overeating; late marriage or inability to form a partnership; loneliness or leaving home; suicidal tendencies [32]. Sever- al studies have also revealed the social aspect of the problem of puberphonia [32,33,34], and researchers with their personal treatment experience have concluded that many other psychosocial problems such as employment and marital issues arise in society. Therefore, the researchers are motivated to find all the consequences of the voice mutation as well as the appropriate treatment model. The most striking consequences of puberphonia are functional communication and social participation. Namely, critical aspects of communication skills are influenced by puberphonia, so adolescents with this functional disorder are teased and bullied more than their peers. Adolescents may not find this voice stigmatizing, however, they prefer not to talk about it with other people. However, in addition to the above, puberphonia can have a broad psychosocial influence. This is especially true for adolescents who may face additional physical, emotional changes as they enter the adult world. A recent study [32] reports the findings of a survey investigating the social and communication impacts of puberphonia. The following messages emerged from the mentioned research, which should be recognized by the public and medical professionals: 1 . Puberphonia is a very common problem; 2 . It is necessary to take advantage of the available treatment; 3 . It is not a hormonal disease or a physiological disease; 4. People with puberphonia are of orderly intelligence; 5 . Inadequate parenting is not the etiology of puberphonia; 6 . This voice disorder is curable.

\section{Diagnosis and possible treatments of puberphonia}

Quality assessment of the voice is very important, because based on it, the vocal therapist designs a treatment plan and program, and implements adequate methods and techniques that include the ultimate care for the voice of each patient [35]. The diagnosis of 
puberphonia relies on auditory-perceptual characteristics, acoustic analysis, laryngovideostroboscopy findings, psychological assessment, tests to exclude hypogonadism, assessment of secondary sexual characteristics, Gutzmann pressure test (external downward pressure on the thyroid cartilage will cause normal voice), as well as clinical examination of the larynx. The diagnostic profile of an individual with puberphonia is relatively simple. Typically, the patients are male after puberty, with relatively normal physical development, including secondary sexual characteristics. The pitch of these patients is significantly higher than expected and similar to the pitch of females. They also rarely have a height that goes through the chest register. Patients lack knowledge of their own potential for a male voice in the chest register and are therefore unaware of how to choose and maintain such a voice [9]. There is a lack of data in the literature on the results of vocal therapy in the case of puberphonia. Recently, there has been a dramatic change in the approach to treating this condition. While older concepts were almost synonymous with vocal therapy, recent trends are prone to surgical correction. Watkinson [36] actually says that surgery is contraindicated in the treatment of puberphonia. Nevertheless, surgical correction of puberphonia is now successfully performed, which has been confirmed through many studies and case reports around the world. In order to decide on a therapeutic modality, we must first define the goals of puberphonia treatment, and regardless of the therapy we apply, the goals must be the same: 1 . The patient should be taught to perform phonation in the lower register; 2 . The patient should be taught to make full use of phonatory and respiratory muscles; 3 . The patient must be convinced that the new, lower voice must be used instead of the old, higher one.

Different therapeutic models are available, mainly categorized into three groups: vocal therapy, digital laryngeal manipulation and surgery. Before undergoing vocal therapy, patients need to be properly consulted on the basics of voice anatomy, human growth, and voice production. This will help alleviate the patient's anxiety before the same therapy. Vocal therapy is a behavioral method to change the way the voice is produced. Therapeutic techniques used in vocal therapy can even improve wound healing after vocal cord injury. Vocal therapy is an effective and appropriate method of treatment either as the only therapy for voice disorder or in combination with other treatment modalities (e.g. surgery, medications). It is considered to be the primary method of treatment of puberphonia [37]. Vocal therapy is traditionally divided into two categories, direct and indirect vocal therapy. A program of vocal therapies that combine direct and indirect approaches is considered to give the best results. Historically, indirect vocal therapy has involved vocal rest. If inadequate or traumatic speech is the cause of voice problems, in most cases the voice temporarily is improved after vocal rest. However, dysphonia usually returns after continued use of the voice. Therefore, vocal rest alone cannot solve the long-term voice problem. Indirect vocal therapy also consists of educating the patient about the dangers of vocal abuse and vocal hygiene. In contrast to indirect, direct vocal therapy involves changing the patient's speech technique in an attempt to increase vocal efficiency and improve voice quality. Vocal therapy usually requires 1-2 sessions once a week for approximately 6-8 weeks. Exceptions exist, including speech therapy before phonosurgery, which is usually limited to a few sessions before surgery and approximately 1-2 weeks after surgery. The techniques of direct vocal therapy focused on puberphonia are as follows: Cough: The patient learns to cough by pressing Adam's apple. This maneuver shortens the length of the vocal cords where it reduces its vibrating tone. The patient is advised to do this exercise at home. This will allow the patient to get 
used to the lower fundamental frequency of the voice. The next technique is masking the range of the voice - this procedure is known to improve the quality of the voice. The use of auditory masking is used to produce a reflex response. Speaking in a noisy background has been found to have deep effects on how an individual speaks. It can change the quality of an individual's speech. This procedure also makes the voice clearer and louder. An instrument known as a facilitator is used for this purpose. Masking is in the range between 100-8000 Hz. Another technique under the guise of direct vocal therapy is a glottal attack before a vowel - The vowel is a very important sound in speech. It is also easily amenable to therapy/change. Glottal attack involves bringing both vocal cords closer. The patient is asked to breathe in and create air pressure in the subglottic area. This causes increased muscle tension in the laryngeal area. The vowel is pronounced as the air is breathed out. This procedure allows a patient to settle down to his basic fundamental frequency of voice. Also, there are techniques for relaxing the laryngeal musculature: Yawn technique, $\mathrm{M}$ warm-up, Visipitch, chewing technique, Boone's technique, Mcfarlane and Boone's Boom swallowing technique [10]. However, there is a lot of controversy about the usefulness of these techniques for relaxing the laryngeal muscles and their effectiveness. Some have even been found to cause damage to the vocal cords [38]. In addition to vocal therapy, there is also laryngeal manipulation as a method of treating puberphonia. This method was first described by Dr Sudhakar Vaidia in his study [34]. Patients were examined under local anesthesia using a Macintosh intubation laryngoscope. The long blade of the laryngoscope was placed in the vallecula and the patient was asked to speak the long "EEE". The pressure in the vallecula stretched the vocal cords. With additional external pressure on the thyroid cartilage, the quality of the voice improved, in the sense that the patient's voice immediately improved from a child's high tone to a lower adult male voice. Digital laryngeal manipulation means that the thyroid cartilage is compressed and the patient is asked to speak. The patient is advised to repeat this procedure at home. Also, injecting botulinum toxin into the cricothyroid muscle could also be helpful. In the same study, it was found that ideally 15 units of Botulinum toxin should be injected in each direction. We can conclude that a conservative approach to the treatment of puberphonia includes speech therapist and otolaryngologist, and that a motivated patient and a dedicated team of therapists usually succeed in treatment in most patients. When this approach to treatment does not work, a surgical option remains in those rare patients. Namely, when all these conservative methods fail, surgery must be the option. The first case of surgical treatment of puberphonia was reported by Pau and Murthi [39].

\section{Conclusion}

Voice is an essential component of individual expression and as a connection with others. As a basic part of one's inner being, the voice is highly influenced by thoughts and self-awareness [40]. The functionality and dysfunction of the voice must be understood within a psychosocial context. Voice characteristics appropriate to age, gender, and cultural background are a critical aspect of functional voice use and consequently successful communication. Future directions in research include replication of existing research and comparisons of various puberphonia treatment techniques to determine efficacy in terms of method/technique and duration of therapy. Also, additional directions include examining participants who belong to other groups, such as individuals with additional communication difficulties. The combination of clinical outcomes with empirical evidence from controlled scientific studies may be most acceptable through a joint effort between clinical environments and 
institutional research. Such combined resources can improve knowledge of functional voice dynamics and psychosocial issues, as well as

Funding source. The authors received no specific funding for this work.

Ethical approval. This article does not contain any studies with human participants performed by any of the authors.

\section{References:}

1. Sataloff RT. Treatment of voice disorders. 2nd ed. San Diego; CA: Plural Publishing; 2017.

2. Maertens K, de Jong FI. The voice handicap index as a tool for assessment of the biopsychosocial impact of voice problems. B-ENT 2007;3(2):61-6.

3. Đoković S, Plećević V, Kovačević T, Šolaja S, Vuković B. Uticaj tonzilektomije na kvalitet glasa. Srp Arh Celok Lek 2020;148(9-10):560-4.

4. Aronson A, Bless DM. Clinical Voice Disorders. 4th ed. New York; Thieme Medical Publishers; 2009.

5. Roy N, Peterson EA, Pierce JL, Smith ME, Houtz DR. Manual laryngeal reposturing as a primary approach for mutational falsetto. Laryngoscope 2017;127(3):645-50.

6. De Alwis ASR, Rupasinghe RJS, Kumarasinghe I, Weerasinghe A, Perera R, Jayasuriya C. Efficacy of voice therapy in patients with puberphonia-a 15-year experience. CJO 2018;7(1):8-11.

7. Sagiroglu S, Kilınc M, Doganer A, Bilal N, Orhan I, Kilic MA. G protein coupled oestrogen receptor 1, aromatase, 17 $\beta$-HSD and cAMP level in mutational falsetto. Eur Arch Otorhinolaryngol 2020;277(4):1121-7.

8. Dağlı M, Sati I, Acar A, Stone RE Jr, Dursun G, Eryilmaz A. Mutational falsetto: intervention outcomes in 45 patients. J Laryngol Otol 2008;122(3):277-81.

9. Hammarberg B. Pitch and quality characteristics of mutational voice disorders before and after therapy. Folia Phoniatr 1987;39(4):204-16. facilitate the establishment of reliable differential diagnostic procedures and the development of treatment approaches.

Conflicts of interest. The authors declare no conflict of interest.

10. Thiagarajan B. Puberphonia Conservative approach A review. Otolaryngology online journal 2015;5(1.5):38-41.

11. Jiang J, Lin E, Hanson DG. Vocal fold physiology. Otolaryngol Clin North Am 2000;33(4):699-718.

12. Kothandaraman S, Thiagarajan B. Mutational falsetto: A panoramic consideration. Otolaryngology online journal 2014;4(1):89-105.

13. Aronson A. Clinical Voice Disorders. New York; Theime; 1990.

14. Gökdoğan Ç, Gökdoğan O, Tutar H, Aydil U, Yllmaz M. Speech Range Profile (SRP) Findings Before and After Mutational Falsetto (Puberphonia). J Voice 2016;30(4):448-51.

15. Vaidya S, Vyas G. Puberphonia: a novel approach to treatment. Indian J Otolaryngol Head Neck Surg 2006;58:20-1.

16. Banerjee AB, Eajlen D, Meohurst R, Murty GE. Puberphonia -A Treatable Entity 1st World Voice Congress Oporto: Portugal; 1995.

17. Hammarberg B. Pitch and quality characteristics of mutational voice disorders before and after therapy. Folia Phoniatr (Basel) 1987;39(4):204-16.

18. Greene CLM, Mathieson L. The Voice and its Disorders, 6th ed. Wiley: Somerset; 2005.

19. Colton RH, Woo P. Measuring vocal fold function, in: J.S. Rubin, R.T. Sataloff, G.S. Korovin (Eds.), Diagnosis and Treatment of Voice Disorders, 3rd ed. Delmar Learning; Albany; 2006, p. 191-219. 
20. Boone DR. Is your voice telling on you? How to find and use your natural voice. 3rd ed. Plural Publishing; 2015.

21. Yogo Y, Ando M, Hashi A, Tsutsui S, Yamada N. Judgments of emotion by nurses and students given double-bind information on a patient's tone of voice and message content. Percept Mot Skills 2000;90(3 Pt 1):855-63.

22. Seifert E, Kollbrunner J. Stress and distress in non-organic voice disorder. Swiss Med Wkly 2005;9;135(27-28):387-97.

23. World Health Organization (WHO), International Classification of Functioning Disability and Health (ICF), WHO, Geneva, Switzerland, 2001.

24. Roy N, Bless DM. Personality traits and psychological factors in voice pathology: a foundation for future research. J Speech Lang Hear Res 2000;43(3):737-48.

25. Rosen DC, Sataloff JB, Sataloff RT. Psychology of voice disorders. 2nd ed. Plural Publishing; 2020.

26. Hamdan AL, Khalifee E, Ghanem A, Jaffal H. Injection Laryngoplasty in Patients With Puberphonia. J Voice 2019;33(4):564-6.

27. Wilson JA, Deary IJ, Millar A, Mackenzie K. The quality of life impact of dysphonia. Clin Otolaryngol Allied Sci 2002;27(3):179-82.

28. Jacobson BH, Johnson A, Grywalski C, Silbergleit A, Jacobson G, Benninger MS, Newman $\mathrm{CW}$. The voice handicap index (VHI) development and validation. Am J Speech Lang Pathol 1997;6(3):66-70.

29. Nissen LS, Schultz J, Galili J, Printz T, Mehlum CS, Grøntved ÅM, Sorensen JR. Crosscultural Adaption and Validation of the Danish Voice Handicap Index-10. J Voice 2020;S0892-1997(19)30460-6.
30. Rosen CA, Murry T, Zinn A, Zullo T, Sonbolian M. Voice handicap index change following treatment of voice disorders. J Voice 2000;14(4):619-23.

31. Benninger MS, Ahuja AS, Gardner G, Grywalski C. Assessing outcomes for dysphonic patients. J Voice 1998;12(4):540-50.

32. Muthiah K, Kumaresan NB. Assess the Impact of Puberphonia in the Society. Int J Otorhinolaryngol 2019;5(2):39.

33. Morrison MD, Nichol H, Rammage L. The management of voice disorders. Springer, 2013.

34. Vaidya S, Vyas G. Puberphonia: A novel approach to treatment. Indian J Otolaryngol Head Neck Surg 2006;58(1):20-1.

35. Ćalasan S, Lazić MP, Simić NJ, Babac S. Akustička struktura glasa kod ispitanika sa umjereno teškim oštećenjem sluha. Biomedicinska istraživanja 2019;10(1):24-9.

36. Watkinson JC, Clarke RW. Scott-Brown's Otorhinolaryngology and Head and Neck Surgery: Volume 3: Head and Neck Surgery, Plastic Surgery. Milton: CRC Press; 2018.

37. Denizoglu II, Sahin M, Bayrak S, Uygun MN. Efficacy of Doctorvox Voice Therapy Technique for Mutational Falsetto. J Voice 2019;33(6):950. e1-950.e8.

38. Pannbacker M. Half-Swallow Boom: Does It Really Happen? Am J Speech Lang Pathol 2001;10:17-8.

39. Pau H, Murty GE. First case of surgically corrected puberphonia. J Laryngol Otol 2001;115(1):60-1.

40. Velsvik Bele I. The Teacher's Voice: Vocal training in teacher education. Scand J Educ Res 2008;52:41-57. 


\section{Puberfonija: od klasičnog do savremenog pristupa}

\section{Bojana Vuković, Slađana Ćalasan}

Univerzitet u Istočnom Sarajevu, Medicinski fakultet Foča, Republika Srpska, Bosna i Hercegovina

Glas je značajna komponenta komunikacije koja nam omogućava prenošenje informacija i izražavanje osjećanja, stoga se posmatra kao temelj verbalne komunikacije. Sazrijevanje tijela obuhvata širenje grkljana i niže pozicioniranje grkljana u vratu, što rezultira višestrukim promjenama u kvalitetu glasa. Brze promjene na ljudskom grkljanu tokom puberteta očiglednije su kod muškaraca. Takve promjene za posljedicu mogu imati mutaciju glasa - puberfoniju. Puberfonija, koja se naziva i mutaciona disfonija ili mutacioni falset je neuspjeh prirodnog smanjenja osnovne frekvencije ili visine tona. Puberfoniju možemo definisati i kao perzistentan adolescentni glas i nakon puberteta u odsustvu organskog uzroka. Ovaj funkcionalni poremećaj glasa može imati višestruke posljedice na ličnost i kvalitet života pojedinca, koji često nailazi na probleme psihološke, emocionalne, socijalne i profesionalne prirode. Ovaj rad ima za cilj da pregleda relevantnu i dostupnu literaturu na temu puberfonije na sveobuhvatan, sažet način, ističući etiologiju, prevalenciju, kliničku manifestaciju, posljedice na kvalitet života osoba sa puberfonijom, kao i evoluciju pristupa i odnosa prema njegovom liječenju.

Ključne riječi: mutacija glasa, pubertet, puberfonija 